\title{
The Influence of Teachers' Role and Motivation on Basic Accounting Learning Outcomes at Vocational High Schools
}

\author{
Filma Alia Sari ${ }^{1}$, Marwan ${ }^{2}$, Sany Dwita ${ }^{3}$ \\ ${ }^{1}$ Faculty of Economics, Universitas Negeri Padang, Padang, Indonesia \\ $\square$ (e-mail) filmaaliasari@gmail.com \\ 2Dept. of Economics Education, Faculty of Economics, Universitas Negeri Padang, Padang, Indonesia \\ $\triangle($ e-mail) marwan@fe.unp.ac.id \\ ${ }^{3}$ Dept. of Accounting, Faculty of Economics, Universitas Negeri Padang, Padang, Indonesia \\ $\square$ (e-mail) sany@fe.unp.ac.id
}

\begin{abstract}
Learning outcomes is students' academic achievement after the completion of learning process. A preliminary survey and prior research show that a large number of students failed to pass basic accounting subject because they do not achieve the minimum learning outcomes required by the schools. This research aims to empirically examine the influence of teachers' role and motivation on students' learning outcomes. This study is expected to facilitate students' success in basic accounting subject through the role of teachers in learning, especially as the appraiser. The role of teachers is expected to improve students' motivation in learning. This study selected sample using proportional random sampling which resulted with 131 students class $X$ at business management vocational high school (Sekolah Menengah Kejuruan-SMK) in city of Solok and Solok regency. The data were collected using a survey questionnaire. The data then were analyzed using path analysis with IBM Amos 21 program. The results show that the teachers' role in learning has a significant and positive influence on learning motivation. The role of teachers in learning has a positive and significant impact on learning outcomes. Moreover, students' learning motivation also has a positive and significant influence on learning outcomes.
\end{abstract}

Keyword: teachers' role in learning, motivation to learn, learning outcomes, and basic accounting subject

\section{Introduction}

The objectives of educational are achieved through the teaching and learning offered at schools and colleges (Akram et al., 2011). Learning is one of the important things in the education system in which the major components are teachers and students (Zohreh et al., 2015). Accounting studies emphasize students' understanding of financial statements, particularly on how to prepare, read, interpret, analyze and communicate financial statements for decision making (Giordano, McAleer \& Szakas, 2010). A basic accounting subject is the foundation for academic building and success in the field of accounting profession later on (AECC, 1992). Tan and Laswad (2006) argue that basic accounting subject is considered as one of the most important subjects as it plays an important role in supporting the academic success of students majoring in accounting. The ability of students to learn the basics of accounting has been of concern to researchers especially in developed countries (Alanzi, 2012). In addition, accounting involves not only technical knowledge and procedures but also the interpretation and referrals (Teixeira and Gomes, 2016).

Dobbins (2014) suggested that learning outcomes is a key element of learning process. Learning outcomes are often used as a measure to find out how far students receive or master the subjects (Sugiono and Rohayati, 2017). Murtonen et al. (2017) states the main purpose of learning outcomes is to help assure the quality of the learning that has been implemented.

Students of vocational high schools (SMK) in city of Solok and Solok regency have faced issues with studnets' learning performance of basic accounting. A large number of students failed to achieve 
learning performance results that meet the minimum criteria required by the school. Tu'u $(2004,76)$ explains that mastery learner is a component output obtained from the results of a learning process. The completeness can be seen by using the parameters of student achievement by looking at the cognitive value, this aspect is assessed by the teacher to see the achievement of student learning outcomes. The data about learning results of basic accounting in vocational students in city of Solok and Solok regency are presented in Table 1.

Table 1 Students' learning outcomes of basic accounting in class $\mathrm{X}$ at SMK Business and Management

\begin{tabular}{lccc}
\hline \multicolumn{1}{c}{ School } & $\begin{array}{c}\text { Completed } \\
\text { (person) }\end{array}$ & $\begin{array}{c}\text { Incomplete } \\
\text { (person) }\end{array}$ & $\begin{array}{c}\text { Total } \\
\text { students }\end{array}$ \\
\hline SMK 1 Solok (city) & 56 & $77(57.9 \%)$ & 133 \\
\hline SMK 2 Gunung Talang (regency) & 16 & $20(55.6 \%)$ & 36 \\
\hline SMK 1 Koto Singkarak (regency) & 5 & $6(54.5 \%)$ & 11 \\
\hline SMK Budi Mulia (regency) & 7 & $11(61.1 \%)$ & 18 \\
\hline Total & $\mathbf{8 4}$ & $\mathbf{1 1 4} \mathbf{( 5 7 . 6 \% )}$ & $\mathbf{1 9 8}$ \\
\hline
\end{tabular}

Source: School Registration Office, Solok, January 2018.

Table 1 shows that the number of mastery learners is still relatively small. Of 133 students in city of Solok, only 56 students who reached the mastery score of 75 while the scores of the other 77 students were under the mastery score. In regency of Solok, which consists of three schools, most students' scores fell under the minimum completeness score. This shows that there is a problem related to students' academic performance in class X at SMK in city of Solok and Solok regency.

One of the solutions for vocational high schools in to improve their students learning results is by improving teachers' role in learning. Akram et al. (2011) suggests that teachers play a basic and dynamic role in the educational system and student learning outcomes depend on effectiveness of teachers' teaching. Nazari (2014) argues that an important factor in the success of a teacher in school is to pay attention to the activities of students in learning activities. Then, Bryson and Hand (2007) find that students were more likely to engage in learning if supported by teachers who built a conducive learning environment.

This is supported by previous studies such as Aini (2008) who reported that teacher role is one of important factor in improving student learning outcomes. Furthermore, Libao (2016) states that the quality of educational experience provided by teachers, related to the teaching and learning methods used, will have an effect on students' success in education. Burchinal (2008) reports that interactions and teachers' role in the learning process are very important. Then, Sartain, Stoelinga and Brown (2011) reported the students who were taught by excellent teachers would perform better than those who were taught by an ordinary teacher.

Another factor that influences student learning outcomes is learning motivation. Learning motivation is the driving force in individuals to do something (Cheng and Southcott, 2016). Motivation can determine how sensitive a person is to learning feedback so that it affects their academic achievement in school (Despasque, 2015). Motivation refers to the underlying reasons for behaviors characterized by students' interest and willingness to learn (Beal and Stevens, 2011). Motivation in learning is underlined as a supporting condition in academic performance and critical thinking in education (Libao et al., 2016). Students who are taught by open questions in the beginning of the lessons tend to have a high level of motivation in learning (Palmer, 2009).

This is supported by research conducted by $\mathrm{Hu}$ et al. (2016) who reported that motivation has a significant effect on students' learning and is a major determinant factor in terms of academic performance or learning outcomes. In addition, Halawah (2006) states that there is a relationship between learning motivation and learning achievement. 
The hypotheses formulated for this study are as follows.

$\mathrm{H}_{1}$ Teachers' role has a significant and positive influence on learning motivation $\mathrm{H}_{2}$ Teachers' role has a significant and positive influence on learning outcomes $\mathrm{H}_{3}$ Learning motivation has a significant and positive influence on learning outcomes

The conceptual model of this study is shown in Figure 1.

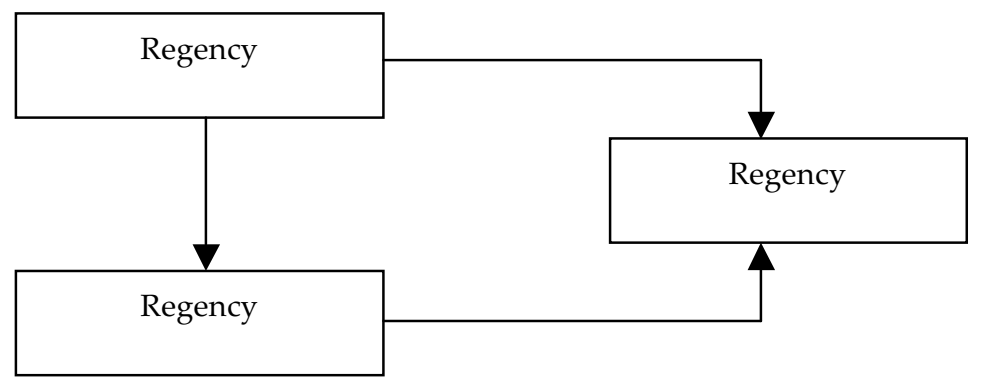

Figure 1 Conceptual framework

\section{Methods}

The type of research used in this research is descriptive and associative. The population in this research was 194 accounting students of class X at vocational high schools (SMK) of business and management in city of Solok and Solok regency. In this study, the sample was selected by proportional random sampling technique that resulted with a sample of 131 students.

The data for this study were collected through a survey questionnaire administered to 131 students. The questionnaire elicited responses by using 5-point Likert scale. For a positive statement, the five alternative answers in the questionnaire range from always (5), often (4), sometimes (3), rarely (2), and never (1), and vice versa for a negative statement. The data collected were analyzed by using path analysis consisting of two sub-structures. The first sub-structure was to empirically test the influence of teacher's role on student's learning motivation. While the second sub-structure was to empirically test the influence of teacher's role and learning motivation on students' learning outcomes.

\section{Results and Discussion}

The research data were collected by distributing questionnaires to 131 accounting students of class $X$ at vocational high school of Business and Management students in city of Solok and Solok regency. Table 2 shows the average respondents' responses related to the independent variables in this study.

Table 2 The frequency distribution of respondents' answers

\begin{tabular}{cllll}
\hline No. & \multicolumn{1}{c}{ Variable's } & Average & TCR $(\%)$ & Category \\
\hline 1. & The teachers' roles & 4.39 & 87.78 & Good \\
2. & Motivation to learn & 3.45 & 68.97 & Enough \\
\hline Source: Primary data, April 2018 & & &
\end{tabular}

Table 2 shows that teachers' role in learning are reported in 'good' category. This means that respondents' answers are able to describe each indicator in the variable well. Whereas, learning motivation is in 'enough' category which indicates that the respondents' responses still do not depict the actual indicator in the variable.

The coefficient of determination $\left(R^{2}\right)$ was used to assess the influence of certain exogenous variables on endogenous variables. The results of the determinant coefficient test can be seen in Table 3 below. The results in Table 2 show that learning outcomes has a coefficient determination of 0.746 . This means that $74.6 \%$ of learning outcomes can be explained by variables of teachers' role and learning while the remaining $25.4 \%$ is explained by other variables that are not examined in the model. Learning motivation has a coefficient of 0.386 . This means that the only $38.6 \%$ of learning 
motivation variable that can be explained by teachers' role while the remaining $61.4 \%$ is explained by other variables that are not examined in this model.

Table 3 The coefficient of determination

\begin{tabular}{lc}
\hline \multicolumn{1}{c}{ Variable } & The value of $\mathrm{R}^{2}$ \\
\hline Learning outcomes $(\mathrm{Y})$ & 0.746 \\
Learning motivation $\left(\mathrm{X}_{2}\right)$ & 0.386 \\
\hline Source: Primary data, April 2018 &
\end{tabular}

The results of the hypotheses test are presented in Table 4. Table 4 shows that all hypotheses in this study is supported since all $\mathrm{t}$-statistic is greater than $\mathrm{t}$-table with significance level (alpha) of $5 \%(0.05)$.

Table 4 Results of hypotheses testing

\begin{tabular}{lcc}
\hline \multicolumn{1}{c}{ Variable } & $\mathrm{t}$-Table & $\mathrm{t}$-statistics \\
\hline Teachers' role --> Motivation & 1.978 & 9.002 \\
Teachers' role --> Learning results & 1.978 & 8.092 \\
Learning Motivation --> Learning & 1.978 & 8.804 \\
outcomes & & \\
\hline Source: Primary data, April 2018 &
\end{tabular}

The first hypothesis proposed that teachers' role in learning has a significant and positive influence on learning motivation. The results of path analysis show a coefficient value of 0.621 which shows the magnitude of influence given by teachers' role on learning motivation of class $\mathrm{X}$ students in the city Solok and Solok regency. The standard error values of 0.062 is the estimated error rate that cannot be explained by the variable examined. Further, $t$-statistics of 9.002 is higher than $t$-table of 1.98 at alpha $5 \%$. Therefore, $\mathrm{H}_{1}$ is supported.

The relationship direction between teachers' role and motivation is positive which means the higher teachers' role in learning the higher students' motivation in learning, and vice versa. It supports that there is a significant and positive influence of teacher's role on learning motivation of class $\mathrm{X}$ students at vocational high schools of business and management.

According to Cheng and Southcott (2016), an understanding of how to motivate students is the key to achieving the desired goals. Furthermore, Cheng and Southcott (2016) suggest that one of the factors that influence students' learning motivation is teachers. Teachers can provide effective and appropriate strategies in motivating their students to learn (Hallam, 2002; McPherson, 2005). One way to motivate students to learn is that teachers can work with parents (Costa-Giomi, 2004, Schatt, 2011). Thus, the teachers' role in teaching can shape students' motivation to be better. As proposed in this study, motivation to learn is an intervening variable in improving learning outcomes in basic accounting subject in vocational high schools.

The second hypothesis proposed that teachers' role in learning has a significant and positive influence on learning outcomes. The results of path analysis show coefficient value of 0.460 . This shows the magnitude of influence given by teachers' role on learning outcomes of class $\mathrm{X}$ students in the city of Solok and Solok regency. The standard error values of 0.040 is the estimated error rate that cannot be explained by the variable examined. Further, $t$-statistics of 8.092 is higher than $t$-table of 1.98 at alpha $5 \%$. Therefore, $\mathrm{H}_{2}$ is supported.

The relationship direction between teachers' role and learning outcomes is positive which means the higher teachers' role in learning, the higher student learning outcomes and vice versa. As such, it supports that there is a significant and positive influence of teacher's role on basic accounting learning outcomes of class $\mathrm{X}$ students at vocational high schools of business and management.

These findings are supported by Ariffin's (2018) who states that the rapid policy changes have been clearly visible in the teachers' quality at all levels. Pang and Miao (2017) argue that many educational systems have acknowledged the contribution of teacher roles to having a positive effect 
on school improvement that is learning outcomes. Furthermore, Lee's (2011) research in Korea show that students have a certain perception on teachers' role in learning and teachers are required to learn how to facilitate and engage in learning with their students. Thus, the teachers' role in teaching can improve students' learning outcomes. So, teachers should be able to play a role in encouraging students to learn to get satisfactory results.

The third hypothesis proposed that students' motivation in learning has a significant and positive influence on learning motivation. The results of path analysis show a coefficient value of 0.500 which shows the magnitude of influence given by teachers' role on learning motivation of class $\mathrm{X}$ students in the city Solok and Solok regency. The standard error values of 0.044 is the estimated error rate that cannot be explained by the variable examined. Further, $t$-statistics of 8.804 is higher than $t$-table of 1.98 at alpha $5 \%$. Therefore, $\mathrm{H}_{3}$ is supported.

The relationship direction between learning motivation and learning outcomes is positive which means the higher students' motivation in learning, the higher students' learning outcomes and vice versa. This it supports that there is a significant and positive influence of learning motivation on basic accounting learning outcomes of class $\mathrm{X}$ students at vocational high schools in business and management.

These findings are supported by $\mathrm{Hu}$ (2016) who shows both internal and external factors have an effect on students' learning motivation. Internal factors include gender, age, personality traits, thinking and learning styles, attributes of learning and self-control. Whereas, external factors are the characteristics of school and classroom, classroom climate, social relationships with teachers and friends, attitudes toward the environment and culture. Furthermore, research by Aritonang (2008) reports that motivation to learn has a positive and significant impact on students' learning outcomes.

Based on these findings, it can be concluded that learning motivation can improve students' learning outcomes. Student learning motivation can come directly within the students themselves or indirectly from outside the students. It is necessary for teachers and parents as well as students to pay attention on ways to motivate students in learning.

\section{Conclusions}

Learning outcomes are one of the important things to indicate the quality of students' learning. Students with good cognitive, affective and psychomotor learning outcomes will be more successful in career world compared to students who do not. The intense competition in the career world requires a student to have a competitive learning outcome in order to compete with other both in the education and career.

The results of pathway analysis explain the indirect and direct influence on learning outcomes. First, teachers' role in learning has an indirect effect on student learning outcomes through learning motivation. This shows that teachers' role in learning play a role in motivating students to be ready for learning. This was created through teachers' role as demonstrator, mediator, evaluator, advisor and role model in learning. Second, the teachers' role in learning and learning motivation directly affects students' learning outcomes.

\section{References}

Accounting Education Change Commission (AECC). (1992). The first course in accounting: Position statement number two. Issues in Accounting Education, 7(2), 249-251.

Aini, Wiwik I. K. (2008). Strategi pengelolaan kelas dalam meningkatkan prestasi belajar siswa. Universitas Muhammadiyah Malang: Malang.

Akram, M.J., et al. (2011). Principals' perception regarding factors affecting the performance of teachers. Journal of International Education Research, 7(2).

Alanzi, K.A. (2012). Some determinants of student performance in principles of financial accounting (ii)-further evidence from Kuwait. Business \& Economics - Qatar University, 16(2), 55-72. 
Ariffin, T., et al. (2018). Framing the roles and responsibilities of excellent teachers: Evidence from Malaysia. Teaching and Teacher Education. Retrieved from: https://doi.org/10.1016/j.tate.2018. 03.005.

Aritonang, K.T. (2008). Minat dan motivasi dalam meningkatkan hasil belajar siswa. Jurnal Pendidikan Penabur, 7(10), 11-21.

Beal, C. R., \& Stevens, R. H. (2011). Improving student's problem solving in a web-based chemistry simulation through embedded metacognitive messages. Technology, Instrumentation, Cognition and Learning, 8(3), 255-271.

Bryson C \& Hand L. (2007). The role of engagement in inspiring teaching and learning. Innovations in Education and Teaching Internationa, 44(4), 349-62.

Burchinal, M., Howes, C., Pianta, R., Bryant, D., Early, D., Clifford, R., et al. (2008). Predicting child outcomes at the end of kindergarten from the quality of pre-kindergarten teacher-child interactions and instruction. Applied Developmental Sciences, 12, 140-153. Retrieved from http://dx.doi.org/10.1080/10888690802199418.

Cheng, Zijia, Southcott, Jane. (2016). Improving students' intrinsic motivation in piano learning: Expert teacher voice. Australian Journal of Music Education. 50(2), 48-57.

Costa-Giomi, E. (2004). I do not want to study piano! Early predictors of students' dropout behavior. Council for Research in Music Education, 161/162, 57-64.

Depasque, Samantha., \& Tricomi, Elizabeth. (2015). Effects of intrinsic motivation on feedback processing during learning. NeuroImage, 119, 175-186.

Dobbins, Kerry., Brooks, Sara., Scott, Jon, J.S., Rawlinson, Mark., \& Norman, Robert. (2014). Understanding and enacting learning outcomes: The academic's perspective. Studies in Higher Education. Retrieved from: http://dx.doi.org/10.1080/03075079.2014.966668.

Giordano, Thomas, McAleer, Brenda, \& Szakas, Joseph S. (2010). Accounting for system analysts in the 21st century. Information Systems Education Journal, 8(42), ISSN:1545-679X.

Halawah, Ibtesam. (2006). The effect of motivation, family environment and student characteristics on academic achievement. Journal of Instructional Psychology, 33(2).

Hallam, S. (2002). Musical motivation: Towards a model synthetizing the research. Music Education Research, 4(2), 225-244.

Hu, Weiping., Jia, Xiaojuan., Jonathan, A., Shan, Xinxin. (2016). Effects of a critical thinking skills program on the learning motivation of primary school students. Roeper Review, 38(2), 70-83, DOI:10.1080/02783193.2016.1150374.

Lee, Dong Yub. (2011). Korean and foreign students' perceptions of the teacher's role in multicultural online learning environment in Korea. Education tech Research Dev. International Review.

Libao, Nhorvien, Jay., Sagun, J.J.B., Tamangan, E.A., Pattalitan, A.P., Dupa, Maria., \& Bautista, Romiro. (2016). Science learning motivation as correlate of students' academic performances. Journal of Technology and Science Education. ISSN:2014-5349. http://dx.doi.org/10.3926/jotse231.

McPherson, G.E. (2005). From child to musician: Skill development during the beginning stages of learning an instrument. Psychology of Music, 33(1), 5-35.

Murtonen, Mari., Gruber, Hans., \& Lehtinen, Erno. (2017). The return of behaviourist epistemology: A review of learning outcomes studies. Educational Research Review, 1747-938X.

Nazari, M. (2014). The relation between teachers' authority styles with sense of security in students of secondary school of Bojnourd country. International Conference of Development and Promotion of Business. Harran.

Palmer, D.H. (2009). Student interest generated during an inquiry skills lesson. Journal of Research in Science Teaching, 46(2), 147-165.

Pang, Nicholas., \& Miao, Zhuang. (2017). The roles of teacher leadership in Shanghai education success. Current Business and Economics Driven Discourse and Education: Perspective from Around the World. Volume 15. Bulgarian Comparative Education Society. ISSN 1314-4693 (print).

Sartain, L., Stoelinga, S., \& Brown, E. (2011). Rethingking teacher evaluation in Chicago. Chicago; The University of Chicago Urban Education Institute. http;//files.eric.ed.gov/fulltext/ED527619.pdf. 
Sugiono, M., \& Rohayati, S. (2017). Pengaruh penggunaan bahan ajar E-BOOK interaktif, pemahaman analisis transaksi dan intensitas latihan soal terhadap hasil belajar siswa pada materi jurnal khusus akuntansi perusahaan dagang kelas XI SMK Negeri 2 Buduran Sidoarjo.

Tan, L.M. and Laswad, F. (2005). Student's beliefs, attitudes and intentions to major in accounting. Accounting Education: An International Journal, 15(2):167-187.

Teixeira, Claudia., \& Gomes, Delfina. (2016). Insights into learning profiles and learning outcomes within introductory accounting. Accounting Education. ISSN: 0963-9284.

Tu'u, Tulus. (2004). Peran Disiplin Pada Perilaku-perilaku Prestasi Siswa. Rineka Cipta: Jakarta.

Zohreh, Esmaeili., Hosein, Mohamadrezai., \& Abdolah, Mohamadrezai. (2015). The role of teacher's authority in students' learning. Journal Education and Practice 6(19). ISSN 2222-1735. 